Meta

Journal des traducteurs

Translators' Journal

\title{
Hebrew-Arabic Translations in the Modern Era: A General Survey
}

\section{Ma'hmoud Khayal}

Volume 43, numéro 1, mars 1998

La traduction et l'interprétation en Israël

Translation and Interpreting in Israel

URI : https://id.erudit.org/iderudit/003311ar

DOI : https://doi.org/10.7202/003311ar

Aller au sommaire du numéro

Éditeur(s)

Les Presses de l'Université de Montréal

ISSN

0026-0452 (imprimé)

1492-1421 (numérique)

Découvrir la revue

Citer cet article

Khayal, M. (1998). Hebrew-Arabic Translations in the Modern Era: A General Survey. Meta, 43(1), 86-94. https://doi.org/10.7202/003311ar
Résumé de l'article

Cet article retrace le développement des activités de traduction d'hébreu en arabe à l'époque moderne. Il prend particulièrement en considération le changement de statut de la langue hébraïque et les réalités politiques complexes et mouvantes dans lesquelles vivent les locuteurs des deux langues. La création de l'État d'Israël, en 1948, constitue un tournant dans ce développement. L'article distingue donc les traductions réalisées dans le monde arabe avant 1948 et celles réalisées après. Il traite également à part des traductions réalisées en Israël. Une étude de chacun des trois groupes révèle des caractéristiques propres à chacun liées à des facteurs concernant l'activité traduisante, le style, le public-cible ou la manière dont les traductions sont reçues. 


\title{
HEBREW-ARABIC TRANSLATIONS IN THE MODERN ERA: A GENERAL SURVEY
}

\author{
MA'HMOUD KHAYAL \\ Tel Aviv University, Tel Aviv, Israel
}

\begin{abstract}
Résumé
Cet article retrace le développement des activités de traduction d'hébreu en arabe à l'époque moderne. Il prend particulièrement en considération le changement de statut de la langue hébraïque et les réalités politiques complexes et mouvantes dans lesquelles vivent les locuteurs des deux langues. La création de l'État d'Israël, en 1948, constitue un tournant dans ce développement. L'article distingue donc les traductions réalisées dans le monde arabe avant 1948 et celles réalisées après. Il traite également à part des traductions réalisées en Israël. Une étude de chacun des trois groupes révèle des caractéristiques propres à chacun liées à des facteurs concernant l'activité traduisante, le style, le public-cible ou la manière dont les traductions sont reçues.
\end{abstract}

\begin{abstract}
This article traces the development of translation activity from Hebrew to Arabic in modern times, while considering in particular the change in the status of the Hebrew language and the intricate and fluctuating political reality in which speakers of the two languages live. The turning point in this development was the establishment of the State of Israel in 1948. Therefore, a distinction is drawn between translations done in the Arab world prior to 1948 and translations done subsequently. On the other hand, the translations done in Israel are discussed separately. An examination of these three groups of translations identifies characteristics unique to each group, and associated with the translation activity itself, style, the target audience or the reception of the translations.
\end{abstract}

\section{INTRODUCTION}

Although the subject of the translations from the European languages into Arabic, done in the various countries of the Arab world, has been treated in many studies (e.g. Somekh 1979; Jacquemond 1992; Hasan 1966), no general, systematic survey of translations from Hebrew to Arabic has yet been conducted. We know of only one study of any sort on Hebrew-Arabic translations (Dahan 1980), but it deals with a linguistic analysis of some of the problems associated with translation work, making no attempt to examine or characterize the scope of such translation activity. It is also true that no full, current bibliography exists for translations from Hebrew to Arabic. Fortunately, partial bibliographies have been prepared for certain areas, e.g. translations of literary works (Zipin 1980) and translations prepared by Palestinian translators (al-Khatib 1995).

In order to discuss the development of Hebrew-Arabic translations, we feel that it is imperative to distinguish between translations undertaken in the Arabic-speaking countries before 1948; such activity carried out in the Arab world after 1948; and translations done in the State of Israel. These distinctions are important because in Israel, in the period after 1948, the Arabic language suffered a significant decline in its status as Hebrew became the dominant language. At the same time, in the Arab world the Arabic language either retained its previous status or, in certain countries (e.g. Algeria), its status was 
enhanced. In parallel, many Arabs came to associate Hebrew more closely with the "Zionist enemy," whereas previously it had been viewed primarily as the language of Jewish worship.

It should be mentioned that over the past century, there has been a Renaissance of both Hebrew and Arabic (albeit for different reasons), resulting in the creation of significant differences between the classical and modern versions of both languages. For Arabic, however, the situation is more complex because the many dialects of spoken Arabic differ significantly from modern literary Arabic. In any case, when we speak of Hebrew-Arabic translation, we mean translation from modern Hebrew to standard Arabic, as defined in various linguistic studies (Stetkevych 1970; Blau 1981; Abdul-Fattah 1987), unless specifically stated otherwise.

\section{HEBREW-ARABIC TRANSLATIONS IN THE ARAB WORLD PRIOR TO 1948}

From the Middle Ages to the modern era, members of the Jewish communities living in the Arab countries used the local dialect of spoken Arabic to communicate in daily life, as did the rest of the population. Only a small number of religious leaders and other educated Jews had mastered classical Hebrew, the language of worship. Thus, there was a need to translate certain basic Jewish texts written in classical Hebrew into Arabic or Judeo-Arabic (Arabic language written in Hebrew characters; see Vajda 1978). Naturally, these Jewish communities devoted most of their translational attention to the Bible and its exegeses. Various translations and adaptations of the Bible were prepared in both Arabic and Judeo-Arabic; most of the translators relied heavily on Sa'adiah Gaon (882 to 942 $\mathrm{CE}$ ), the Egyptian-born Jewish scholar who had translated the Bible into classical Arabic in the 10th century (Avishur 1988; Zafrani 1980).

In the 19th century, the Old and New Testaments were translated from their original languages into Arabic on the initiative of Catholic and Protestant missionaries, who themselves played an active role as translators. These works, based in part on ancient translations of the Scriptures (including that of Sa'adiah Gaon), were written in a peculiar Arabic style (Blau 1966), yet even today some are still used by Arab readers as an aid to understanding the Bible (Somekh 1995). Because of these works, the Arab world was, for the first time, exposed to an Arabic version of the Bible.

It would seem that the first modern, non-religious, Hebrew work to be translated into Arabic was Abraham Mapu's proto-Zionist novel Ahavat Zion (Love of Zion, 1853). Translated by Salim al-Dawudi, secretary of the rabbinical court of the Jewish community of Cairo, it was published in Cairo in two editions: the first appeared in 1899, and the second in two parts, in 1921 and 1922. Written in literary Arabic, the work is rife with grammatical and syntactical errors. Evidently, the author did not intend to produce a work in exemplary Arabic, but rather sought to demonstrate to Arabic-speaking Jews that Hebrew

was a living language (Ben-Dor 1981). This work was followed by a small number of translations, chiefly in Arabic newspapers, that were carried out by Jews conversant with both languages, such as Nissim Malul (Somekh 1984).

\section{HEBREW-ARABIC TRANSLATIONS IN THE ARAB WORLD AFTER 1948}

Hebrew, considered by educated Arabs to be a language of the past, became, after the establishment of the State of Israel, the language of the Arab world's principal enemy. As a result, the Arab armies and Palestinian organizations paid some attention to its acquisition. However, until 1967 almost no translations from Hebrew were published. The reasons for this are several: 
a) In the Arab world, the training of new generations of translators was hindered by the fact that whereas spoken Hebrew had undergone considerable development in a short span of time, the Arab universities continued to teach classical Hebrew as part of their curriculum of ancient Semitic languages. The problem was aggravated because modern Hebrew-Arabic lexicography, which began in 1911 with the appearance of the Qestin dictionary, was unable to keep pace with the momentum of the renewal of the Hebrew and Arabic languages (Somekh 1990).

b) Of the few translations which were carried out, many remained secret for military reasons and were not published for the civilian market (Hejazi 1995).

c) Because Israel was viewed as having been forced on the Arab national movement and the Palestinian people, an atmosphere of hostility to Israel reigned in Arab intellectual circles. This situation discouraged potential translators, including those who did know Hebrew, from producing translations.

d) Translation activity from the European languages into Arabic, which began in the late 19th century, satisfied the demands of educated Arabs interested in foreign works in the fields of literature, science, philosophy, etc.

However, after the 1967 Mideast war some Hebrew-Arabic translations began to appear. The chief reason for the change seems to be that in the wake of the crushing defeat suffered by the Arab armies, the Arab intelligentsia became more aware that a familiarity with Israeli society would be of value in the war effort (al-Bahrawi 1977 : 11). Several other factors also contributed to the increase in translations after 1967:

i) A not insignificant number of institutions, some veteran and others newly established, became active in the field of Israeli studies and in the translation of books intended to give readers a better understanding of Israeli society. Two Beirut-based institutions deserve special mention: the Institute of Palestine Studies, founded by Arab businessmen and intellectuals in 1963; and the Palestine Research Centre, founded by the PLO in 1965 (al-Khatib 1995 : 44).

ii) Publishers became interested in studies and translations dealing with Israel. One publishing house worthy of special mention is Dar al-Jalil in Jordan, founded by a Palestinian who once held Israeli citizenship.

iii) Researchers and academics, especially those working in the field of Hebrew language and literature, began to take the initiative, publishing studies in their fields of expertise and participating in the activities of institutions and publishers interested in furthering the study of Israeli society.

All these factors succeeded in imparting a certain momentum to the field of HebrewArabic translations. However, there were still far fewer translations from Hebrew than from other foreign languages. According to Jacquemond (1992), out of a total of 29,627 books published in Egypt in Arabic during the years 1968-1982, the number of translated books was 1950 , or $6.6 \%$ of the total. According to our statistics, the number of works translated from Hebrew to Arabic in the entire Arab world during the same period was 30, that is to say, less than one percent of all the translated works published. During the last few years, there has been an increase in the number of books being translated from Hebrew, apparently because of the peace treaties signed between Israel and Egypt, Jordan and the Palestinians. However, there has been no significant change in the percentage of such translations relative to translations from other languages. 


\section{The Characteristics of Hebrew-Arabic Translations in the Arab World}

Many of the translations from Hebrew that were done in the Arab countries in the shadow of the continuing confrontation with Israel were motivated by the slogan "know your enemy" and were intended to provide useful information concerning all facets of Israeli life (al-Khatib 1995 : 60). Under such circumstances, one would expect to find selective and slanted translations rather than works intended to promote normal cultural contacts. And indeed, among the Hebrew-Arabic works translated in the Arab world, some of them through the medium of another foreign language, the number dealing with matters connected with Israel's politics, military and intelligence services is overwhelming. For example, of the 42 translated works published by Dar al-Jalil in Jordan between the years 1981-1990, most of them translated from Hebrew, only two books did not deal directly with these subjects.

Even in the realm of Hebrew literature, most of the Arab translators approached their material as being primarily of historical, social and political interest. As a result, most Hebrew-Arabic translations of literary works were accompanied by commentaries and footnotes reflecting the political opinions of the translators and publishers. The choice of material for translation was also politically motivated: selected works were, more often than not, intended to buttress the political positions of the translator or publisher.

In translations done in the Arab world, one often comes across imprecise renderings resulting from the use of intermediary translations (mainly in English) or from a lack of familiarity with the Hebrew language and Israeli culture.

\section{Hebrew-Arabic Translators in the Arab World}

The Hebrew-Arabic translators who have worked in the Arab countries can be divided into four main groups:

a) Scholars of Hebrew language and literature at the Arab universities, e.g. 'Ain Shams University in Egypt, one of the leaders in this field.

b) Translators who learned Hebrew within a military or intelligence framework.

c) Palestinians who learned Hebrew from direct contact with Israelis in various circumstances. Prominent among this group are individuals who were expelled from Israel after being accused of belonging to the PLO organizations, e.g. Ghazi al-Sa'di and Habib Qahwaji. In recent years, Palestinian Arabs living in Israel have been increasingly involved in the field of Hebrew-Arabic translation.

d) Writers, journalists and other educated people who considered translation from Hebrew to be important and who sought to make their own contribution to the field, their lack of knowledge of Hebrew notwithstanding. Naturally, such translators did their work using intermediary translations, principally in English.

\section{The Distribution and Reception of the Translations in the Arab World}

We have no data concerning the distribution of Hebrew books in Arabic translation, but it seems to us that such works have been directed principally at people interested in various aspects of the Israeli-Arab conflict. Given that the Palestinians see themselves as the chief victims of the Arab-Israeli conflict, it comes as no surprise that Palestinian institutions and publishers have played a leading role in sponsoring translations from Hebrew, and that Palestinian journals have devoted special attention to such translations. In addition, many Palestinians living in the Arab countries are involved in translating from Hebrew, e.g. Ahmad 'Omar Shahin in Egypt, Jawdat al-Sa'd in Syria and Ghazi al-Sa'di in Jordan. 
Egypt, too, has played an important role in the development of Hebrew-Arabic translations. Because the Egyptian universities are among the leading Arab institutions of higher studies in the field of Hebrew language and literature, they have brought about the involvement of many Egyptian academics in translation and have been directly responsible for the undertaking of research relating to Israeli culture. However, in the wake of the Camp David Accords, signed by Israel and Egypt in 1979, an impassioned debate arose in Egypt over the desirability of "cultural normalization" between the two countries, and many members of Egypt's nationalist, leftist and Islamic movements regularly express strenuous objections to what they call Israel's "cultural invasion" of the Arab world (Qasem 1988). This opposition to "normalization" has led to impediments to Hebrew-Arabic translating activity, in part because people who might otherwise have taken part have been deterred from participating in what some interpret as collaboration with the normalization process. As a result, most translation activity in Egypt has remained within an academic framework. However, over the last few years, as Israel has signed two additional peace treaties (with Jordan and the PLO), it would seem that despite the criticism of an Israeli "cultural invasion," Egypt has seen increased activity in the field of Hebrew-Arabic translation. For instance, beginning in 1994 the Egyptian publisher al-Dar al-'Arabiyya decided to bring out a series of translated literary works; so far two Hebrew novels have appeared. In addition, in 1995 the prestigious Egyptian literary journal $I b d a^{\prime}$ published three special issues devoted to Israeli culture. The editorial board of al-Ahram, Egypt's leading daily, continues to publish a magazine, Mukhtarat Isra'iliyya ("Selected Israeli Passages"), which includes translations from Hebrew newspapers.

None of this can be seen as proof of a significant change in the suspicions that many Egyptian intellectuals harbour about Israeli culture. While some in the Arab world have come to the conclusion that translations from Hebrew cannot possibly influence Arab culture, others believe that until all aspects of the Israeli-Arab conflict have been resolved, new and more efficient ways to combat Israeli culture - accused by many of racism and aggression (Hejazi 1995; Qasem 1988) - must be sought.

In other Arab countries, it would appear that the field of Hebrew-Arabic translation is quite limited. We know very little about the activities of the University of Baghdad's Palestine Studies Centre, which, according to the reports of an Egyptian scholar who worked at the Centre, deals with Hebrew-Arabic translations (al-Bahrawi 1977 : 11-12). We are equally in the dark about the work of Syrian scholars in the field of Hebrew language and literature, although some of them, such as Ribhi Kamal, are considered experts in Hebrew. However, we do know that in the universities of the Gulf states, especially Saudi Arabia, an interest has been shown in learning Hebrew, and to that end a number of Egyptian scholars have been employed there (al-Bahrawi 1994 : 7).

\section{TRANSLATIONS IN ISRAEL AFTER 1948}

In the late 19th and early 20th centuries, Palestine saw the development of translation activity from various foreign (mainly European) languages into Arabic. Al-Khatib (1995 : 159-171), for instance, lists 94 books translated by Palestinians between 1898 and 1948. However, only one of them was translated from Hebrew.

After 1948, the number of works translated from Hebrew into Arabic increased considerably. Al-Khatib's list, which according to the author does not include translations done by Jews or translations of textbooks, includes 83 books translated into Arabic and published in the State of Israel between 1948 and 1985: 36 from Hebrew, 25 from other languages (chiefly English) and 22 whose original language is not specified (al-Khatib 1995 : 171-251). This list, which is neither comprehensive nor up-to-date and which 
ignores entire spheres of translation, nevertheless bears witness to a significant change in the percentage of translations from Hebrew relative to other source languages. In our opinion, there are several reasons for the change:

1) The Arabs of mandatory Palestine, a majority until 1948, became a minority in the territories incorporated into Israel after the 1948 Mideast war. Hebrew thus ceased to be the dominant language of the society in which Israel's Arab citizens found themselves.

Despite the fact that Arabic was proclaimed one of the two official languages of the State of Israel, it was for all intents and purposes superseded by Hebrew (for a more detailed discussion of the status of the two languages in Israel, see the article by Amit-Kochavi in this volume). The intensive use of Hebrew in the workplace, in academic institutions, in government offices and in other areas of life greatly enhanced its practical importance and status. This situation forced the Arabs to learn Hebrew in order to participate in Israel's economic, political and social life, to the point that empirical research has demonstrated the clear influence of Hebrew on the Arabic spoken in Israel (Amara and Spolsky 1986); in parallel, it created interest in works originally written in Hebrew and translated into Arabic. Since the early 1980s, some Arab authors, such as Na'im 'Araidi and Anton Shammas, have chosen to write in Hebrew (Hever 1987).

2) The Arab population which remained in Israel after the 1948 war was overwhelmingly rural and suffered from a high rate of illiteracy, most educated Arabs having left Israeli territory because of the war (Winter 1981). As a result, the field of translation was dealt a serious blow, as were other cultural enterprises. At the same time, the accelerated process of modernization which the Arab population underwent, due to the nature of Israeli society, created the need for a wide range of textbooks, practical guides, reference works, etc. The easiest way to procure such texts was to translate works from Hebrew.

3) A number of bodies and organizations initiated and encouraged Hebrew-Arabic translations to further their own aims. These included:

a) Government-affiliated institutions, which encouraged translations for a variety of reasons, e.g. to serve the educational and economic needs of the Arab sector, to encourage and facilitate the integration of Arab Israelis in Israeli society, and to counter the anti-Israel propaganda spread by the Arab countries.

b) Commercial enterprises seeking to promote sales in the Arab sector.

c) The print and electronic media, which sought to cater to Arab readers, listeners and viewing audiences.

These initiatives have resulted in diverse, wide-ranging translation activity whose scope makes it difficult to keep account of, especially because many of the translations (especially the non-literary ones) are scattered among scores of newspapers, magazines, periodicals, pamphlets, practical guides, textbooks, television programs, etc. It is also difficult to keep track of translated literary works, since these, too, appear in so many different forums. Without the efforts of Israel's Institute for the Translation of Hebrew Literature, it would be virtually impossible to track down all the works that are listed in the Institute's bibliographies (Goldberg 1988; Raz and Kandelshein 1993; Zipin 1980). Zipin (1980), for example, lists 832 full or excerpted works translated from Hebrew into Arabic in Israel during the years 1948 to 1979; of these, 678 are poems. He also notes that during the same period, 17 full-length books appeared: nine collections of poetry, three novels, four collections of short stories and an anthology of poetry and prose (Zipin 1980). 


\section{Characteristics of Hebrew-Arabic Translating in Israel}

Hebrew-Arabic translations cannot be considered en bloc because, as we have noted above, such texts are quite diverse, both in subject matter and because of the multiplicity of organisations and bodies responsible for their publication. However, it is generally true that the non-literary translations are, for the most part, overly literal, and many suffer from a lack of precision in their Arabic grammar and syntax, perhaps the result of a belief that a strict adherence to the source text would not impair comprehensibility. This imprecision is particularly conspicuous in official translations of government publications, but it can also be found in television subtitles (most translated first into Hebrew and then into Arabic), as well as in certain textbooks in use in Arab schools, in which one can find scientific terms invented by the translator and "new" names for Arab localities based on transliterations from Hebrew. These phenomena may be the result of employing non-professional translators lacking a full command of literary Arabic, or of translation work that was done hastily and was not properly edited. A further possible explanation is that many translations were done with the sponsorship and oversight of people or organisations whose main priority was that the translator remain faithful to the original text.

In the realm of literary translations, there was a tendency to favour free translation during the 1950s and 1960s; however, from the 1970s to the present there has been no clear trend, and translation guidelines have, for the most part, been dictated by the experience and personal inclinations of the translator as well as by the approach of the person responsible for a given translation project. In general, however, it can be stated that the tendency is toward producing an adequate translation, faithful to the source, rather than an equivalent translation that takes into consideration the target language.

\section{Translators in Israel}

Most Hebrew-Arabic translators in Israel have not been full-time professionals and have worked in the field only occasionally and without long-term commitment. This would explain why so much poetry has been translated, since short pieces do not require a huge time investment.

The translators active in Israel have not received appropriate professional instruction, since until 1994 there was no framework for the training of qualified Hebrew-Arabic translators. Indeed, any Arab graduate of an Israeli university might be considered a potential translator, on the assumption that he or she had mastered both languages. In many situations, translators have been selected in part because of personal and business ties. Nevertheless, a number of experienced translators, chiefly those engaged in literary work (e.g. Anton Shammas, Muhammad Ghanayim), have made significant contributions to the field of Hebrew-Arabic translation and have achieved a certain degree of renown.

Hebrew-Arabic translators in Israel can be divided into two main groups: the first, active mainly in the 1950s and 1960s, is composed of Jews who had come to Israel from the Arab countries (e.g. Nir Shochit and Meir Hadad); the second, which began working in the middle of the 1960s, consists of Israeli Arabs (e.g. Anton Shammas and Mahmoud 'Abbasi).

\section{The Circulation and Reception of Translations in Israel}

The importance of Hebrew-Arabic translations and the reception they have received has depended in great measure on the prevailing conditions in Israeli Arab society. During the 1950s and early 1960s, when the population was mainly agrarian, illiterate and cut off from the Arab world, Hebrew-Arabic translations played an important role in facilitating the participation of the Arabs in Israeli society. However, three factors contributed to a decline in the importance of translations from Hebrew: 1) the Arab population began to 
learn Hebrew; 2) the number of educated people increased; and 3) ties with the Arab world were renewed after 1967, via the West Bank and the Gaza Strip.

Other factors may also have adversely affected the chances of such translations being sympathetically received by the Arab population of Israel:

1) The field of Hebrew-Arabic translation in Israel was almost completely cut off from the Palestinian Arabs' pre-1948 tradition of translation activities from all languages, in part because the most important translators of the prewar period had become refugees. As a result, Hebrew-Arabic translators had no solid tradition to fall back on, unlike their counterparts in the Arab world, who, working from the European languages (chiefly English, French and Russian), still functioned within a wellestablished tradition.

2) Most translated works were commissioned, produced and published by government bodies and institutions, towards which many Israeli Arabs felt a sense of alienation.

3) The quality of the translations, more than once criticized for ignoring the rules of correct Arabic grammar and syntax (see Moreh 1979), was often poor due to the inexperience of many of the translators, the haste with which many translations were produced and the fact that they rarely benefited from the requisite linguistic editing.

4) Very few of the Hebrew-Arabic translations carried out in Israel succeeded in finding publishers in the Arab world, a circumstance which adversely impacted their status among Israeli Arabs. In general, such translations received scathing criticism from Arab left-wing and nationalist groups, who accused them of disseminating $\mathrm{Zi}$ onist propaganda (Ghanayim 1986). In addition, publishers in the Arab world were reluctant to accept works that, people complained, had been garbled beyond comprehension (Bar-Yosef 1994).

Given the difficulties noted above, it comes as no surprise that there is a clear tendency for educated Israeli Arabs either to ignore translations and read books in Hebrew, or to write new works in Arabic instead of relying on translated material originally created for a Hebrew-speaking audience. In recent years, more and more textbooks have been written in Arabic, thus reducing reliance on Hebrew textbooks, either translated or untranslated. As for translated Hebrew literature, there are many indications that, unlike translations from the European languages, it has remained on the margins of Arabic-language literature in Israel. Arab writers and intellectuals view Arabic literature produced in Israel as an integral part of both Palestinian and pan-Arab literature rather than part of the same cultural milieu that produces Israel's Hebrew literature (Snir $1993: 23$ ).

The majority of the main organisations involved in Hebrew-Arabic translations have been in some way affiliated with the Israeli government or establishment. In the 1950s and 1960s, extensive translating activity took place under the auspices of government ministries and the Histadrut (Israel's major labor union). During this period, establishment bodies were also prominent in the publishing field. For instance, many translations were published by the Histadrut's Arabic-language publishing house, Dar al-Nashr al-'Arabi.

Beginning in the 1970s, independent and left-wing groups and organisations began publishing large numbers of translated works, especially after the Arabic-language establishment newspapers closed down and the above-mentioned Histadrut publisher cut back its activity. Today, one of Israel's major independent, Arabic-language publishers is Dar alMashreq, which has produced many translated works since the 1980s. Government and establishment groups have not ceased their involvement in translation work, but their involvement now tends to be indirect, via groups or institutions which receive government 
aid: the Institute for the Translation of Hebrew Literature, for example, or the magazine Liqa', which deals with both Hebrew-Arabic and Arabic-Hebrew translations.

\section{CONCLUSIONS}

Since the beginning of the 20th century, translation from Hebrew to Arabic has been a diverse undertaking. At least three different translation enterprises can be discerned: translations carried out before 1948, translations done in the Arab world after 1948, and translations done in the State of Israel. Guided by considerations that differed from - and sometimes clashed with - each other, each of these enterprises was the product of dynamic political and cultural circumstances whose far-reaching repercussions have had a profound effect on the relative status of Hebrew and Arabic and on other aspects of the relationship between the two languages. There is no way of knowing whether recent political developments will lead to significant changes in the status of Hebrew-Arabic translations in the coming years, but it can be expected that the cooperation between the two sectors of Hebrew-Arabic translation - one in Israel, the other in the Arab countries will be heightened, and that the translations done in Israel will have to adapt to the norms that predominate in the Arab world.

\section{REFERENCES}

ABDUL-FATTAH, Nazek (1987) : Nominal Patterns in Hebrew, an Introductory Survey, Cairo.

AL-BAHRAWI, Ibrahim (1977) : The Zionist Literature between Two Wars June 1967 - October 1973, Beirut, alMu'assasa al-'Arabiyya. (Arabic)

AL-BAHRAWI, Ibrahim (1994) : The Arabic Culture and the Israeli Conflict Culture, Cairo, Dar al-Zahra'. (Arabic)

AL-KHATIB, Hosam (1995) : Palestinian Translating Activity from the Renaissance to the 20th Century, Beirut, al-Mu'assasa al-'Arabiyya. (Arabic)

AMARA, M. A. \& B. SPOLSKY (1986) : "The Diffusion and Integration of Hebrew and English Lexical Items in the Arabic Spoken in an Israeli Village", Anthropological Linguistics, 28, pp. 43-54.

AVISHUR, Y. (1988) : "Modern Judeo-Arabic Translations of the Bible in the Orient: A Cultural-Linguistic Presentation", Moshe Bar-Asher (Ed.), Studies in Jewish Languages, Jerusalem, Misgav Yerushalayim, pp. 39-82. (Hebrew)

BAR-YOSEF, Y. (1994) : "Wishing to Translate from Hebrew into Arabic", Yedioth Ahronoth, October 28 , p. 31. (Hebrew)

BEN-DOR, Yisrael (1981) : "The Translation of 'Ahavat Zion' ('Love of Zion') into Arabic by Salim al-Dawudi at the End of the Previous Century", Bama'rakhah, 250, pp. 26-27. (Hebrew)

BLAU, J. (1966) : A Grammar of Christian Arabic, Louvain, Secrétariat du Corpus.

BLAU, Joshua (1981) : The Renaissance of Modern Hebrew and Modern Standard Arabic, Berkeley, University of California Press.

DAHAN, Hiya (1980) : A Linguistic Analysis of Some Problems of Translation from Modern Hebrew into Arabic Based Upon Selected Translations of Literary and Political Prose, Jerusalem, Hebrew University of Jerusalem, Unpublished Ph.D. Dissertation. (Hebrew)

GHANAYIM, Muhammad (1986) : "Do we Try to do Something Impossible?", Liqa', 3 (7), p. 3. (Arabic)

GOLDBERG, Isaac (Ed.) (1988) : Bibliography of Modern Hebrew Literature in Translation, Ramat Gan, the Institute for the Translation of Hebrew Literature.

HEJAZI, Ahmad 'Abd al-Mo'ati (1995) : "Just a Beginning", Ibda', 3, pp. 4-5. (Arabic)

HASAN, Muhammad 'Abd al-Ghani (1966): The Art of Translation in Arabic Literature, Cairo. (Arabic)

HEVER, H. (1987) : "Hebrew in Israeli Arab Hand: Six Miniatures on Anton Shammas's Arabesques", Cultural Critique, 7, pp. 47-76.

JACQUEMOND, Richard (1992) : "Translation and Cultural Hegemony — the Case of French-Arabic Translation", Lawrence Venuti (Ed.), Rethinking Translation: Discourse, Subjectivity, Ideology, London, Routledge, pp. 139-158.

MOREH, S. (1979) : "David Rokach in Arabic Dress", Hamizrach Hechadash, 28, pp. 326-327. (Hebrew)

QASEM, Qasem 'Abdoh (1988) : "On the Israeli Conflict — the Dangers of Arab Absence from the Cultural Front", Fekr, 13, pp. 100-111. (Arabic) 
RAZ, Nilli \& Essi KANDELSHEIN (Eds) (1993) : Bibliography of Modern Hebrew Literature in Translation, Ramat Gan, the Institute for the Translation of Hebrew Literature.

SNIR, R. (1993) : "Original and Translation on Contact Line", S. Somekh (Ed.), Translation as a Challenge, Tel Aviv, Tel Aviv University, pp. 21-39. (Hebrew)

SOMEKH, Sasson (1979) : "Arabic Translations of Literary Works in the 19th Century", Hasifrut, 28, pp. 52-57. (Hebrew)

SOMEKH, Sasson (1984) : "Rashed Hussein Translates Bialik", Iton 77, 54-55, pp. 30-31. (Hebrew)

SOMEKH, Sasson (1990) : "Introduction", David Sagiv, Hebrew-Arabic Dictionary of the Contemporary Hebrew Language, Tel Aviv, Schocken, Vol. 1. (Hebrew, Arabic)

SOMEKH, Sasson (1995) : "Biblical Echoes in Modern Arabic Literature", Journal of Arabic Literature, 26, pp. 186-200.

STETKEVYCH, Jaroslav (1970) : The Modern Arabic Literary Language: Lexical and Stylistic Developments, Chicago, University of Chicago Press.

VAJDA, G. (1978) : "Judeo-Arabic", The Encyclopaedia of Islam, Leiden, 2nd ed., Vol. 4, pp. 299-307.

WINTER, Michael (1981) : "Basic Problems of the Educational System", Aharon Layish (Ed.), The Arabs in Israel - Continuity and Change, Jerusalem, Magnes Press, pp. 168-179. (Hebrew)

ZAFRANI, H. (1980) : Littératures dialectales et populaires juives en Occident musulman, Paris, Geuthner. ZIPIN, Amnon (1980) : Bibliography of Modern Hebrew Literature in Arabic Translation 1948-1979, Tel Aviv, the Institute for the Translation of Hebrew Literature. (Arabic) 